\title{
Development of a sensitive and rapid chromogenic factor IX assay for clinical use
}

Citation for published version (APA):

Wagenvoort, R., Hendrix, H., Tran, T., \& Hemker, H. C. (1990). Development of a sensitive and rapid chromogenic factor IX assay for clinical use. Haemostasis, 20(5), 276-288.

https://doi.org/10.1159/000216139

Document status and date:

Published: 01/01/1990

DOI:

10.1159/000216139

Document Version:

Other version

\section{Please check the document version of this publication:}

- A submitted manuscript is the version of the article upon submission and before peer-review. There can be important differences between the submitted version and the official published version of record.

People interested in the research are advised to contact the author for the final version of the publication, or visit the DOI to the publisher's website.

- The final author version and the galley proof are versions of the publication after peer review.

- The final published version features the final layout of the paper including the volume, issue and page numbers.

Link to publication

\footnotetext{
General rights rights.

- You may freely distribute the URL identifying the publication in the public portal. please follow below link for the End User Agreement:

www.umlib.nl/taverne-license

Take down policy

If you believe that this document breaches copyright please contact us at:

repository@maastrichtuniversity.nl

providing details and we will investigate your claim.
}

Copyright and moral rights for the publications made accessible in the public portal are retained by the authors and/or other copyright owners and it is a condition of accessing publications that users recognise and abide by the legal requirements associated with these

- Users may download and print one copy of any publication from the public portal for the purpose of private study or research.

- You may not further distribute the material or use it for any profit-making activity or commercial gain

If the publication is distributed under the terms of Article $25 \mathrm{fa}$ of the Dutch Copyright Act, indicated by the "Taverne" license above, 


\title{
Development of a Sensitive and Rapid Chromogenic Factor IX Assay for Clinical Use
}

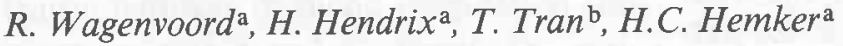 \\ a Department of Biochemistry, University of Limburg, Maastricht, The Netherlands; \\ ${ }^{b}$ Baxter Dade AG, Düdingen, Switzerland
}

Key Words. Chromogenic assay · Factor VIII purification · Factor IX · Factor $\mathrm{X}$ activation

Abstract. A chromogenic factor IX assay is developed which requires only two timedependent steps. Diluted plasma is mixed with a reagent containing factors VIII and X. The reaction is started by addition of a reagent containing factor $\mathrm{XI}_{\mathrm{a}}$, thrombin, $\mathrm{CaCl}_{2}$, and phospholipids. Then factor $\mathrm{XI}_{\mathrm{a}}$ activates factor IX if present, thrombin activates factor VIII, and subsequently the complete factor $\mathrm{X}$ activating complex (factor $\mathrm{IX}_{\mathrm{a}}$, factor $\mathrm{VIII}_{\mathrm{a}}$, Ca ions, and phospholipids) rapidly activates factor X. Finally, ethylenediaminetetraacetic acid plus a chromogenic substrate are added to stop the reaction and to measure formed factor $\mathrm{X}_{\mathrm{a}}$. Factor $\mathrm{X}_{\mathrm{a}}$ formation is proportional to the plasma factor IX concentration (from 0 to $140 \%$ ). The two reagents needed for the assay are stable at room temperature during a whole working day and for $3 \mathrm{~h}$ at $37^{\circ} \mathrm{C}$. A new isolation procedure for factor VIII is described. Factor VIII is purified from bovine plasma in a few steps with a yield of $20 \%$ and a 8,000 -fold purification.

\section{Introduction}

Factor IX (Christmas factor) is an important zymogen of the blood coagulation. Deficiency of this protein in blood leads to bleeding problems: hemophilia B [see ref. 1 for a review]. Factor IX is a vitamin $\mathrm{K}$ dependent protein and thus contains $\gamma$-carboxyglutamic acid residues. These $\gamma$-carboxyglutamic acid residues are possibly involved in the binding of factor IX (and also other vitamin $\mathrm{K}$ dependent clotting factors) to negatively charged phospholipid membranes via calcium bridges [2]. Human factor IX is a glycoprotein with a carbohydrate content of about $17 \%$ and with an apparent molecular weight of $57,000[3,4]$. The plasma concentration is 46-88 $\mathrm{n} M$. Factor IX can be activated by fac- 
tor $\mathrm{XI}_{\mathrm{a}}$ and by the factor $\mathrm{VII}_{\mathrm{a}}$-tissue factor complex. Both enzymes cleave the same bonds in factor IX which results in a twochain factor IX $_{\mathrm{a}} \beta$ and an activation peptide $(\mathrm{Mr}=11,000)$.

Factor $I_{\mathrm{a}}$ is an important enzyme of the intrinsic pathway of blood coagulation [for reviews see refs. 5 and 6]. Factor IX $_{a}$ activates factor $\mathrm{X}$ in a reaction that is accelerated enormously by factor $\mathrm{VIII}_{\mathrm{a}}$, phospholipids, and calcium ions [7]. Several methods are described to measure factor $\mathrm{IX}_{\mathrm{a}}$ : a clotting assay using factor IX deficient plasma [8], a method based on the esterase activity of factor IX $_{\mathrm{a}}$ using radiolabeled esters [9], a method to determine the release of the tritiated activation peptide which originally was described by Silverberg et al. [10], an immunoradiometric assay [11], a spectrometric assay described by Tans et al. [12], and an active-site titration with $p$-nitrophenyl-p-guanidino benzoate hydrochloride [13]. All these methods (except the clotting assay which, however, is not very precise) have the disadvantage of being laborious and thus are unsuited for a routine determination in a clinical laboratory.

In order to measure factor IX quantitatively, (1) it has to be activated, and (2) the formed factor $\mathrm{IX}_{\mathrm{a}}$ should activate factor $\mathrm{X}$ under conditions that factor $\mathrm{IX}_{\mathrm{a}}$ is the ratelimiting compound. In this paper we searched for optimal reaction conditions and a procedure to minimize the incubation time and the pipetting steps. For a chromogenic factor IX assay we do not need a $100 \%$ pure factor VIII; however, the preparation should not contain fibrinogen or other components that interfere with the assay. In this paper we describe the isolation of bovine factor VIII

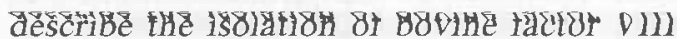
that meets the conditions for a well-working s. यर

fastor IX assav

\section{Materials and Methods}

\section{Materials}

$\mathrm{FX}_{\mathrm{a}}$ substrate $\left(\mathrm{CH}_{3} \mathrm{OCO}-\mathrm{D}\right.$-CHG-Gly-Arg- $p$ NA$\mathrm{AcOH})$ and $\alpha$-NAPAP [N- $\alpha$-(2-naphthylsulfonylglycyl)- $D, L$-amidinophenyl-alanine-piperidide hydroidide] were obtained from Pentapharm (Switzerland); Sphérosil X 015 LS was from Rhône Poulenc (France); Sephadex G-25 fine was from Pharmacia (Sweden); immunoadsorbed factor IX deficient plasma was donated by Baxter Dade (Switzerland); S2337 [N-benzoyl- $L$-isoleucyl- $L$-glutamyl-(piperidyl)- $L$-glycyl- $L$-arginine-p-nitroanilide hydrochloride], S2238 (H- $D$-phenylalanyl- $L$-pipecolyl- $L$-arginine- $p$-nitroanilide dihydrochloride) and RVV-X (factor $\mathrm{X}$ activator from Russell's viper venom) were from Kabi (Sweden).

All other reagents were of the highest grade commercially available.

\section{Phospholipids and Phospholipid Vesicles}

Phosphatidylcholine was extracted from egg yolks according to the method of Bligh and Dyer [14] and purified as described by Comfurius and Zwaal [15]. Phosphatidylserine was prepared in a similar way, however, extracted from bovine brains. Vesicles were prepared by sonication of a phospholipid mixture in a buffer containing $50 \mathrm{mM}$ Tris- $\mathrm{HCl}$ and $175 \mathrm{mM}$ $\mathrm{NaCl}$ (pH 7.9) using an MSE Mark II 150-watt ultrasonic disintegrator set at $9 \mu$ peak-to-peak amplitude. The composition of the vesicles was $75 \mathrm{~mol} \%$ phosphatidylcholine and $25 \mathrm{~mol} \%$ phosphatidylserine or as indicated.

\section{Proteins}

All proteins were isolated from bovine plasma. Factor $\mathrm{X}$ was isolated according to the method of Fujikawa et al. [16]. Human factor IX [see refs. 17 and 18] was a gift of T. Janssen-Claessen. Factor IX was prepared by activating human factor IX with isolated factor $\mathrm{XI}_{\mathrm{a}}$ according to the method of Fujikawa et al. [19]. Bovine factor $\mathrm{XI}_{a}$ (contact product) was isolated as described by Nossel [20] and Østerud and Rapaport [21]. Prothrombin was isolated according to the method of Owen et al. [22]. Thrombin was prepared from prothrombin by activation with prothrombinase as described elsewhere [23].

Factor VIII was measured as described by Wagen-

Factor VIII was measured as described by Wagenvoord et al. [24]. As reference plasma normal pooled

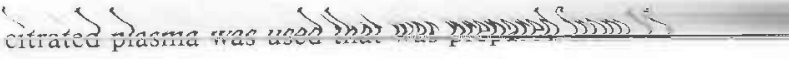

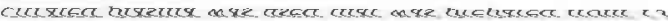


healthy donors; the plasma was donated by T. Janssen-Claessen. The reference plasma was compared a few times with the reference plasma provided by Baxter (CoagCal). Both plasmas contained the same amount of factor VIII; differences of less than $3 \%$ were found. By definition, normal pooled plasma contains $1 \mathrm{U} / \mathrm{ml}$ factor VIII.

To measure factor $\mathrm{X}_{\mathrm{a}}$ formation in time, samples of the reaction mixture were added to a cuvette containing $20 \mathrm{mM}$ ethylenediaminetetraacetic acid in standard buffer (see below). The final volume after subsampling was $980 \mu \mathrm{l}$. Factor $\mathrm{X}_{\mathrm{a}}$ then was measured by addition of $20 \mu \mathrm{l}$ of $4 \mathrm{mMFX}$ substrate plus $50 \mu M a$-NAPAP to the cuvette [see ref. 24]. $\alpha$-NAPAP was added to the $\mathrm{FX}_{\mathrm{a}}$ substrate to inhibit hydrolysis of this chromogenic substrate by thrombin. $1 \mu M \alpha$-NAPAP inhibits thrombin by $99.5 \%$ [24].

\section{Reaction Conditions}

All reactions were done at $37^{\circ} \mathrm{C}$; in each case the reagents were preincubated at $37^{\circ} \mathrm{C}$ during $5 \mathrm{~min}$. All proteins were dissolved in $175 \mathrm{mM} \mathrm{NaCl}$ and $50 \mathrm{mM}$ Tris- $\mathrm{HCl}$ (standard buffer). All dilutions were done in the same buffer containing $0.5 \mathrm{mg} / \mathrm{ml}$ ovalbumin.

\section{Results}

\section{Isolation of Factor VIII}

Bovine blood was collected in 10-liter vessels containing 1 liter $100 \mathrm{mM}$ benzamidine, $100 \mathrm{mM}$ sodium citrate, $20 \mathrm{U} / \mathrm{ml}$ heparin, and $100 \mathrm{mg} / 1$ soybean trypsin inhibitor. The next steps were done at $0-4^{\circ} \mathrm{C}$. The blood was centrifuged at $5,000 \mathrm{~g}$ during 15 min. The plasma was collected and to the plasma was added polyethylene glycol $20,000(1.8 \%, w / v)$. The mixture was stirred during $10 \mathrm{~min}$, and then the formed precipitation was spun down at $2,000 \mathrm{~g}(10 \mathrm{~min})$. The precipitate was dissolved in $120 \mathrm{mM}$ $\mathrm{NaCl}$ and $10 \mathrm{mM}$ trisodium citrate (final volume about one twentieth of the plasma volume). To the solution was added $50 \mathrm{mM}$ $\beta$-mercaptoethanol, and the mixture was incubated during the night at $0^{\circ} \mathrm{C}$. Next day the formed precipitation was spun down at $5,000 \mathrm{~g}$ during $30 \mathrm{~min}$. The supernatant usually was frozen at $-80^{\circ} \mathrm{C}$ until further use.

A few factor VIII preparations were thawed and combined. To the preparation was added Sphérosil PL (4 g/l). Sphérosil PL was prepared by addition of $5 \%(\mathrm{w} / \mathrm{w})$ phospholipids dissolved in chloroform $(10 \mathrm{mg} /$ $\mathrm{ml})$ to Sphérosil (X $015 \mathrm{LS}$ ). The phospholipid composition was $95 \mathrm{~mol} \%$ phosphatidylcholine and $5 \mathrm{~mol} \%$ phosphatidylserine. The chloroform was evaporated in vacuum until dryness. Then the Sphérosil PL was washed with isotonic salt. The factor VIII preparation was stirred during the night with the Sphérosil PL at room temperature. Next day the Sphérosil PL was collected and poured into a small column $\left(5 \mathrm{~cm}^{2}\right)$. The Sphérosil PL was washed very carefully with isotonic salt. Factor VIII was eluted from Sphérosil PL with $1 M$ sodium thiocyanate and $1 M \mathrm{NaCl}(\mathrm{pH} 6.2)$. The eluted factor VIII was gel filtrated immediately to remove the salt by elution on a Sephadex G-25 column $\left(50 \times 5 \mathrm{~cm}^{3}\right)$ which was equilibrated with $175 \mathrm{mM} \mathrm{NaCl}$ and $50 \mathrm{~m} M$ Tris- $\mathrm{HCl}$ (pH 7.9). The activity of factor VIII varied from 100 to $250 \mathrm{U} / \mathrm{ml}$. The optical density at $280 \mathrm{~nm}$ of the preparations was about 1 . The obtained preparation did not promote platelet aggregation, so it is free of active von Willebrand factor.

\section{Properties of Factor VIII}

We have determined the amount of thrombin that is needed for complete activation of factor VIII. In figure 1 the result of this experiment is shown. One can observe that remarkably high concentrations of thrombin (more than $100 \mathrm{n} M$ ) are necessary to activate factor VIII completely. 
The amount of activated factor VIII necessary for complete saturation of the factor $\mathrm{IX}_{\mathrm{a}}$ was determined in a similar way as described by Van Dieijen et al. [25]. In a mixture containing human factor $\mathrm{IX}_{\mathrm{a}}$, $\mathrm{CaCl}_{2}$, phospholipid vesicles, thrombin, and factor $\mathrm{X}$, the factor VIII concentration was varied $(1.25-10 \mathrm{U} / \mathrm{ml})$. In this reaction mixture, the factor $\mathrm{X}$ activating reaction was linear, with the reaction time between 15 and $90 \mathrm{~s}$. The reaction rates were plotted double reciprocally against the factor VIII concentrations, obtaining straight lines from which the kinetic constants of the reaction were calculated. The $\mathrm{V}_{\max }$ is $4.256 \mathrm{nM} / \mathrm{min}$, and the turnover number is 851 (moles factor $\mathrm{X}_{\mathrm{a}}$ formed per minute per mole factor $\mathrm{IX}_{\mathrm{a}}$ ). To obtain a half maximal reaction rate, $3.64 \mathrm{U} / \mathrm{ml}$ factor VIII is required. This means that very high factor VIII concentrations are necessary to saturate the factor $\mathrm{X}$ activating complex almost completely. For a $90 \%$ saturation, already $32.8 \mathrm{U} / \mathrm{ml}$ factor VIII is required. By increasing the final $\mathrm{CaCl}_{2}$ concentration to $13.4 \mathrm{mM}$, the $\mathrm{V}_{\max }$ was hardly changed (792); however, the amount of factor VIII necessary for a half maximal rate increased tenfold $(32.8 \mathrm{U} / \mathrm{ml})$. This means that by increasing the $\mathrm{CaCl}_{2}$ concentration, the affinity of factor $\mathrm{VIII}_{\mathrm{a}}$ to the factor $\mathrm{X}$ activating complex decreases. So it is possible to modulate the reaction rate by changing the $\mathrm{CaCl}_{2}$ concentration.

In the same way as described by Van Dieijen et al. [25] we have determined the molar concentration of $1 \mathrm{U} / \mathrm{ml}$ factor VIII. At a very low factor VIII concentration $(1 / 120 \mathrm{U} / \mathrm{ml})$, the assay was saturated with excess of factor $\mathrm{IX}_{\mathrm{a}}$. We found that the dissociation constant of factor $\mathrm{IX}_{\mathrm{a}}$ for the factor $\mathrm{X}$ activating complex was $17.3 \mathrm{nM}$, and the maximal rate of factor $X_{a}$ formation was

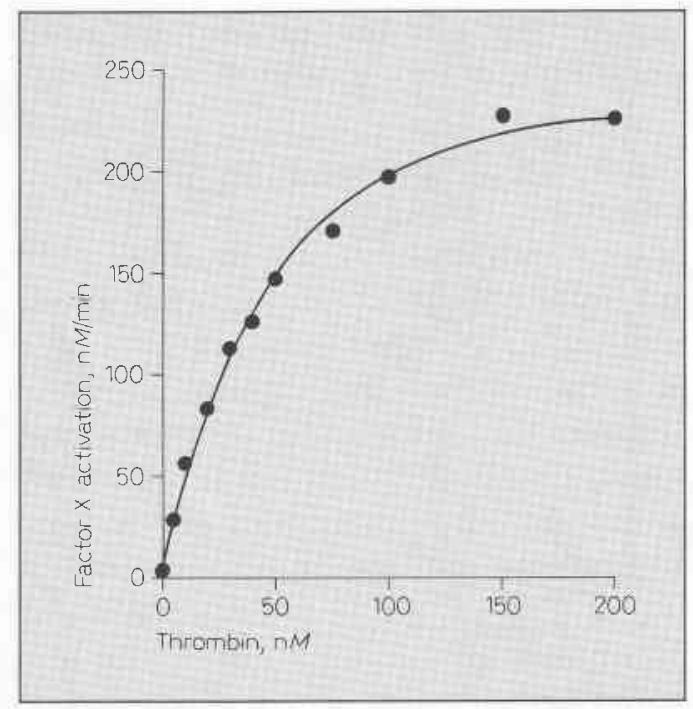

Fig. 1. Activation of factor VIII as a function of the thrombin concentration. Factor VIII $(5 \mathrm{U} / \mathrm{ml})$ was activated with thrombin during $15 \mathrm{~s}$ in the presence of $5 \mathrm{mM} \mathrm{CaCl}_{2}$. Forty microliters of the activated factor VIII was added to $160 \mu \mathrm{l}$ of $1.25 \mu M$ factor $\mathrm{X}$, $25 \mu M$ phospholipid vesicles, $5 \mathrm{mM} \mathrm{CaCl}$, and $25 \mathrm{n} M$ factor $\mathrm{IX}_{\mathrm{a}}$. Samples of $20 \mu \mathrm{l}$ were taken at 20 and $40 \mathrm{~s}$ reaction time, and the factor $\mathrm{X}_{\mathrm{a}}$ formation was measured.

$4.88 \mathrm{n} M / \mathrm{min}$. From these data we have calculated that $1 \mathrm{U} / \mathrm{ml}$ factor VIII equals $0.688 \mathrm{nM}$, assuming that factors $\mathrm{VIII}_{\mathrm{a}}$ and $\mathrm{IX}_{\mathrm{a}}$ are present in the factor $\mathrm{X}$ activating complex at equimolar amounts [25].

The results described above have shown that for practical reasons it is not possible to work with saturating amounts of factor VIII; this means that the rate of factor $\mathrm{X}_{\mathrm{a}}$ formation depends on the factor VIII concentration in the reaction mixture. For that reason we have studied the stability of the factor VIII at $37^{\circ} \mathrm{C}$. Figure 2 shows that factor VIII is not stable in the absence of $\mathrm{CaCl}_{2}$; however, when $0.1 \mathrm{mM} \mathrm{CaCl}$ is present, factor VIII is stable. The activity in the absence 


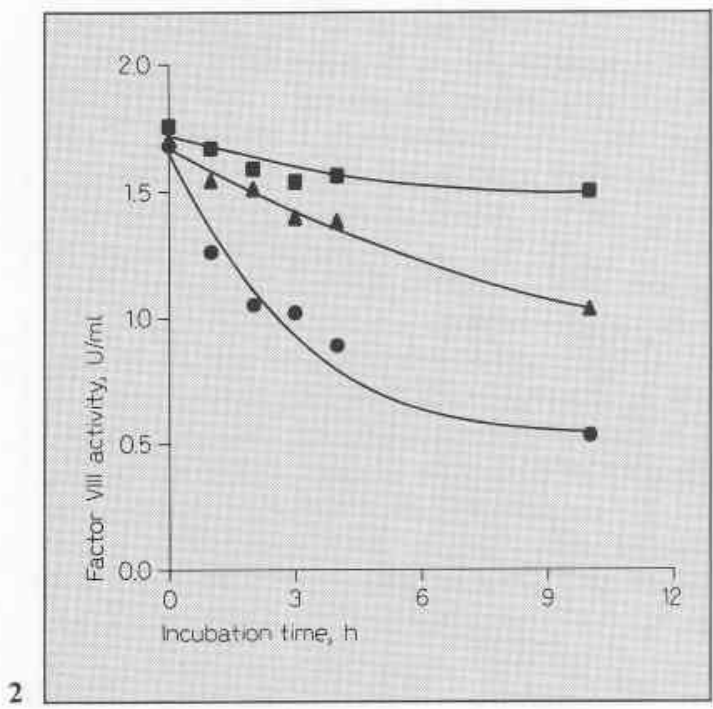

Fig. 2. Stability of diluted factor VIII at $37^{\circ} \mathrm{C}$. Factor VIII was diluted to about $1.7 \mathrm{U} / \mathrm{ml}$ in standard buffer containing $2.0 \mathrm{mg} / \mathrm{ml}$ ovalbumin and no $(\bullet)$, $25 \mu M(\Delta)$, or $100 \mu M$ ( $\mathbf{( a )} \mathrm{CaCl}_{2}$.

Fig. 3. Activation of human factor IX with factor $\mathrm{XI}_{\mathrm{a}}$. To $100 \mu \mathrm{l} 400 \mathrm{n} M$ thrombin, $80 \mu M$ phospholipid vesicles, and $15 \mathrm{mM} \mathrm{CaCl} 2$ was added $100 \mu \mathrm{l}$

of $\mathrm{CaCl}_{2}$ dropped by $68 \%$ after $10 \mathrm{~h}$ at $37^{\circ} \mathrm{C}$, whereas in the presence of $0.1 \mathrm{mM}$ $\mathrm{CaCl}_{2}$ the activity dropped by only $20 \%$. So, by addition of $0.1 \mathrm{mM} \mathrm{CaCl}$ to the reagent with factor VIII, it is sufficiently stable to use in the chromogenic factor IX assay.

\section{Optimization of the Factor IX Assay}

We have determined the optimal concentrations of factor $\mathrm{XI}_{\mathrm{a}}$, phospholipid vesicles, and factor $\mathrm{X}$ for a well-working chromogenic factor IX assay.

In figure 3 we have determined the concentration of factor $\mathrm{XI}_{\mathrm{a}}$ that is necessary to activate human factor IX completely within $2 \mathrm{~min}$. This concentration is about $1.0 \mathrm{n} M$.

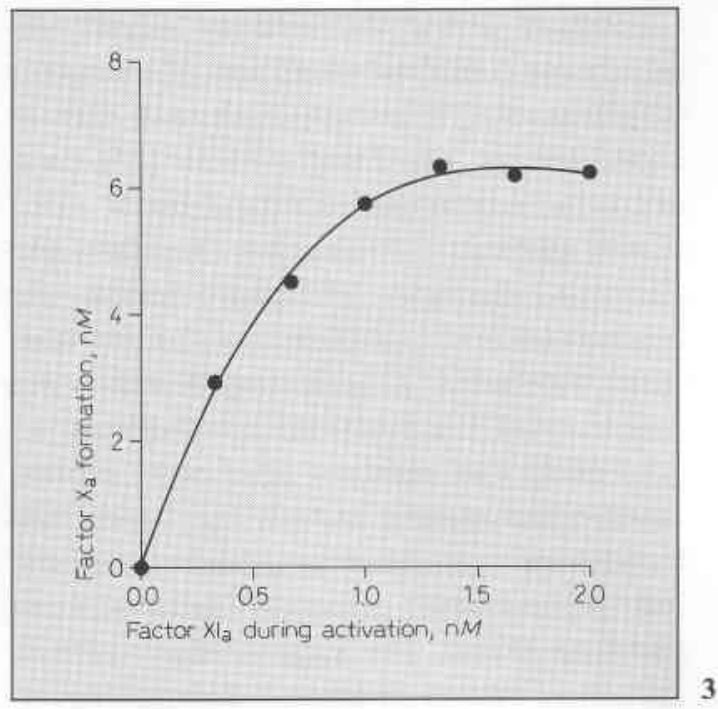

factor $\mathrm{XI}_{\mathrm{a}}$ of $0,1,2,3,4,5$, and $6 \mathrm{n} M$. At $\mathrm{t}=0 \mathrm{~min}$ $100 \mu \mathrm{l}$ human factor IX $(50 \mathrm{p} M)$ was added and at $\mathrm{t}=$ $2 \mathrm{~min} 100 \mu \mathrm{l}$ of a mixture containing $2.5 \mathrm{U} / \mathrm{ml}$ factor VIII, $1 \mu M$ factor $\mathrm{X}$, and $5 \mathrm{mM} \mathrm{CaCl} 2$. At $\mathrm{t}=4 \mathrm{~min}$ samples of $200 \mu \mathrm{l}$ were taken, and the formed factor $\mathrm{X}_{\mathrm{a}}$ was measured. To correct for hydrolysis of $\mathrm{FX}_{\mathrm{a}}$ substrate by factor $\mathrm{XI}_{a}$, the same experiment was done without factor $\mathrm{X}$.

The dependency of the assay on phospholipid concentration and composition is very similar as described by Van Dieijen et al. [7] and Wagenvoord et al. [24]. For that reason only the results of these studies are given. The reaction rate is maximal at a phospholipid concentration of $8 \mu M(25 \mathrm{~mol} \%$ phosphatidylserine, $75 \mathrm{~mol} \%$ phosphatidylcholine). At higher concentrations the activity slowly decreases, and at lower concentration it sharply drops to almost zero in the absence of phospholipids. We have also studied whether changing the composition of the phospholipids affects the reaction rate. Addition of cholesterol or phosphatidylethanolamine to the vesicles did not lead to higher 


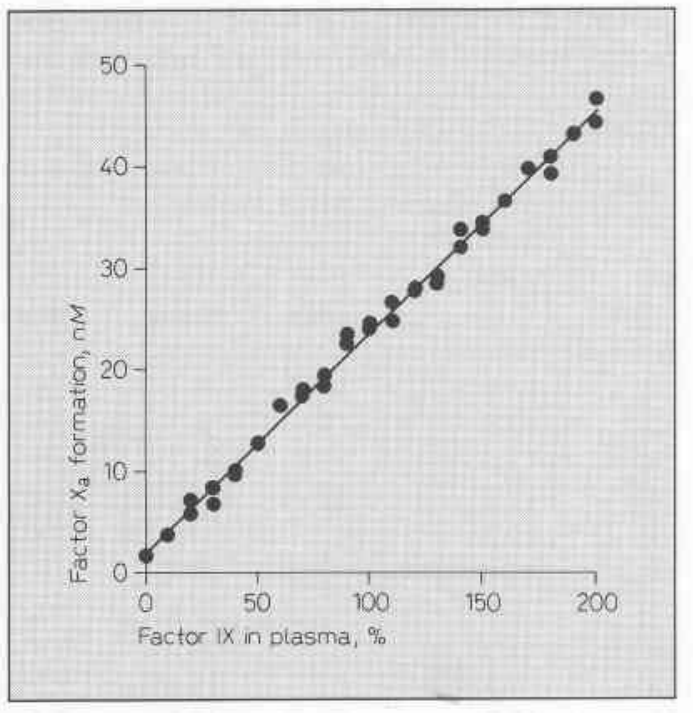

Fig. 4. Factor IX assay of plasmas with variable amounts of factor IX. Immunoadsorbed factor IX deficient plasma was 200 times diluted in standard buffer ( $0 \%$ factor IX), normal pooled plasma was 200 times diluted (100\% factor IX) and 100 times diluted ( $200 \%$ plasma) in the same buffer. By mixing the diluted plasmas, we prepared plasmas with $0-200 \%$ factor IX. The pipetting sequence was: at $\mathrm{t}=0 \mathrm{~min}$ $100 \mu$ l reagent 1 (300 $\mathrm{n} M$ thrombin, $15 \mathrm{~m} M \mathrm{CaCl}_{2}$, $2 \mathrm{n} M$ factor $\mathrm{XI}_{\mathrm{a}}, 60 \mu M$ phospholipid) was mixed with $100 \mu \mathrm{l}$ diluted plasma; at $\mathrm{t}=2 \min 100 \mu \mathrm{l}$ reagent 2 ( $1 \mu M$ factor $\mathrm{X}, 3 \mathrm{U} / \mathrm{ml}$ factor VIII, $0.1 \mathrm{mM}$ $\mathrm{CaCl}_{2}$ ) was added, and at $\mathrm{t}=4 \mathrm{~min}$ samples of $100 \mu \mathrm{l}$ were taken to measure formed factor $\mathbf{X}_{\mathrm{a}}$.

reaction rates, and changing the ratio between phosphatidylcholine and phosphatidylserine from 10 to 2 in the vesicles did not lead to higher activities.

In a similar way as described by Wagenvoord et al. [24], the $K_{m}$ of factor $X$ activation by the complete factor $\mathrm{X}$ activating complex was determined. The $\mathrm{K}_{\mathrm{m}}$ is $45 \mathrm{n} M$. The $\mathrm{K}_{\mathrm{m}}$ is comparable with that found in the case of factor VIII assay [24]. Although in that case the composition of the factor $\mathrm{X}$ activating complex was different, it was composed of bovine factor $\mathrm{IX}_{\mathrm{a}}$ and human factor VIII $_{\mathrm{a}}$.

The results described above have shown that an optimal factor IX assay is obtained when the factor $\mathrm{XI}_{\mathrm{a}}$ concentration is $1 \mathrm{n} M$ during factor IX activation, the thrombin concentration during factor VIII activation is $100 \mathrm{n} M$ or more, and the final factor $\mathrm{X}$ concentration is far above the $\mathrm{K}_{\mathrm{m}}(300 \mathrm{n} M)$. We decided to use $20 \mu M$ phospholipids because at this concentration the reaction is not very much dependent on the phospholipid concentration.

It was shown that very high factor VIII concentrations are required to bind all factor $\mathrm{IX}_{\mathrm{a}}$ in the factor $\mathrm{X}$ activating complex. For practical reasons it is not possible to use such high amounts of factor VIII on large scale. For that reason we have investigated whether the formed factor $\mathrm{X}_{\mathrm{a}}$ is linearly dependent on the factor IX concentration under conditions that factor VIII is not saturating.

\section{Properties of the Factor IX Assay}

To minimize pipetting steps we have prepared two reagents with compositions based on the above-described results. Reagent 1 contained $300 \mathrm{n} M$ thrombin, $15 \mathrm{mM} \mathrm{CaCl}$, $2 \mathrm{n} M$ factor $\mathrm{XI}_{\mathrm{a}}$, and $60 \mu M$ phospholipid vesicles. Reagent 2 contained $1 \mu M$ factor $\mathrm{X}$, $3 \mathrm{U} / \mathrm{ml}$ factor VIII, and $0.1 \mathrm{~m} M \mathrm{CaCl}_{2}$. The $\mathrm{CaCl}_{2}$ in reagent 2 is added to stabilize the factor VIII. The generally used pipetting sequence was: at $\mathrm{t}=0 \mathrm{~min} 100 \mu \mathrm{l}$ of reagent 1 was mixed with $100 \mu \mathrm{l}$ diluted plasma, at $\mathrm{t}=$ $2 \min 100 \mu \mathrm{l}$ of reagent 2 was added, and at $\mathrm{t}=4 \mathrm{~min}$ samples of $100 \mu \mathrm{l}$ were taken to measure formed factor $\mathrm{X}_{\mathrm{a}}$.

Figure 4 shows that the assay is linear with the percentage factor IX in the plasma 
Table 1. Stability of the factor IX assay reagents

\begin{tabular}{llllc}
\hline \multicolumn{2}{l}{ Incubation } & & & \multicolumn{2}{l}{ Activity } \\
\cline { 1 - 2 } \cline { 5 - 5 } time, h & $\begin{array}{c}\text { temperature } \\
{ }^{\circ} \mathrm{C}\end{array}$ & & $\begin{array}{l}\text { factor } \mathrm{X}_{\mathrm{a}} \\
\mathrm{n} M / \mathrm{min}\end{array}$ & $\%$ \\
\hline 0 & 22 & & 27.3 & 100 \\
4 & 22 & 25.9 & 94.9 \\
24 & 22 & 25.2 & 92.6 \\
\hline 0 & 37 & 27.3 & 100 \\
1 & 37 & 26.9 & 98.5 \\
3 & 37 & 25.7 & 94.4 \\
\hline
\end{tabular}

Method and composition of the reagents 1 and 2 are described in text. At the indicated incubation time, a fresh plasma dilution was made (normal pooled plasma, 200 times diluted).

up to $200 \%$, although the factor VIII concentration is $1 \mathrm{U} / \mathrm{ml}$ which is below the $K_{d}$.

Because we use nonsaturating factor VIII concentrations in the factor IX assay, the assay is sensitive for inactivation of factor VIII. The other clotting factors are present in excess, so changes in their concentration would not affect the reaction rate very much. We have prepared the reagents 1 and 2 and tested whether they are stable at $37^{\circ} \mathrm{C}$ and at room temperature. In table 1 the results of these tests are shown. One can notice that even after $3 \mathrm{~h}$ at $37^{\circ} \mathrm{C}$ or after $24 \mathrm{~h}$ at $22^{\circ} \mathrm{C}$ (ambient temperature) the assay is stable within $7.4 \%$.

Factor IX Detection in Different Plasmas with Modified Reagents

For clinical application of the chromogenic factor IX assay, plasma dilutions of 1 in 200 are not practical. In clinics one would like to dilute the plasma in one step. Plasma dilutions of 1 in 31 or 1 in 41 are more suit-
Table 2. Determination of factor IX in plasmas of patients treated chronically with oral anticoagulants

\begin{tabular}{rllll}
\hline Plasma & \multicolumn{4}{l}{ Factor IX in plasma, \% } \\
\cline { 2 - 5 } & $\begin{array}{l}\text { chromogenic } \\
\text { factor IX }\end{array}$ & \multicolumn{2}{l}{ APTT method } \\
\cline { 3 - 5 } & assay & 5 & 10 & 100 \\
& & times & times & times \\
\hline \multirow{2}{*}{1} & 14.6 & 24.6 & 21.8 & 12.8 \\
2 & 13.8 & 23.3 & 20.5 & 11.5 \\
3 & 13.6 & 25.5 & 21.8 & 11.7 \\
4 & 12.3 & 22.9 & 20.2 & 11.3 \\
5 & 19.2 & & 30.3 & 15.9 \\
6 & 23.4 & & 29.4 & 17.4 \\
7 & 20.6 & & 27.1 & 14.6 \\
8 & 15.0 & & 20.0 & 12.8 \\
9 & 9.5 & & 15.8 & 7.3 \\
10 & 12.9 & & 17.5 & 7.4 \\
11 & 14.6 & & 21.4 & 10.5 \\
12 & 17.6 & & 27.1 & 14.2 \\
13 & 24.2 & & 35.4 & 18.3 \\
14 & 11.6 & & 20.2 & 11.3 \\
15 & 26.6 & & 32.9 & 17.7 \\
16 & 16.3 & & 26.9 & 15.4 \\
\hline
\end{tabular}

Factor IX was measured in two ways: either using the modified chromogenic factor IX assay described in figure $5 \mathrm{~b}$ or the standard APTT method using factor IX deficient plasma; as $100 \%$ we used either five times, ten times, or 20 times diluted reference plasma (CoagCal, Baxter). In the last case the plasma samples were diluted 100 times, and corrections were made to account for the additional dilution.

able. However, the reaction rate would be far too high when the reaction conditions shown in figure 4 are used. As was described above, the reaction rate can be decreased by increasing the $\mathrm{CaCl}_{2}$ concentration of the reaction mixture. The reaction rates can be decreased also by addition of smaller plasma volumes to the reaction mixture. For those reasons we prepared modified reagents 1 and 2 and 


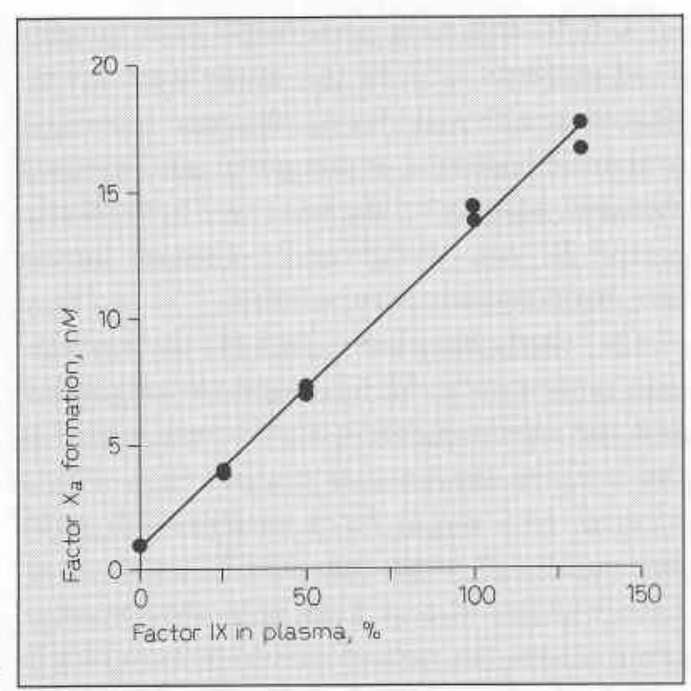

Fig. 5. Standard curves for the chromogenic factor IX assay. Two modified reagents were prepared. The modified reagent 1 contained $225 \mathrm{n} M$ thrombin, $45 \mu M$ phospholipid vesicles, $30 \mathrm{~m} M \mathrm{CaCl}_{2}$, and $1.25 \mathrm{n} M$ factor $\mathrm{XI}_{\mathrm{a}}$. The modified reagent 2 contained $1.5 \mathrm{U} / \mathrm{ml}$ factor VIII, $750 \mathrm{n} M$ factor $\mathrm{X}$, and $0.1 \mathrm{mM} \mathrm{CaCl} 2$. Normal pooled plasma was diluted in isotonic salt $31,41,82$, and 164 times. For the blank isotonic salt was used. The plasma dilution 1 in 41 is called $100 \%$. a The pipetting scheme was: at $t=0 \mathrm{~min}$ $100 \mu \mathrm{l}$ reagent 1 was mixed with $25 \mu \mathrm{l}$ diluted plasma,

changed the pipetting sequence somewhat (see legend to figure 5). By having present FX $_{a}$ substrate in the stop buffer, factor $\mathrm{X}_{\mathrm{a}}$ was measured immediately, and one subsampling step was avoided. By mixing reagent 2 with the diluted plasma, starting the reaction with reagent 1 and terminating the reaction after 3 min by addition of stop buffer, the procedure was simplified even more.

Figure 5a shows a reference curve of factor IX determinations in human plasma with the modified chromogenic factor IX assay. Normal pooled plasma was diluted as indicated. A dilution of 1 in 41 is called $100 \%$

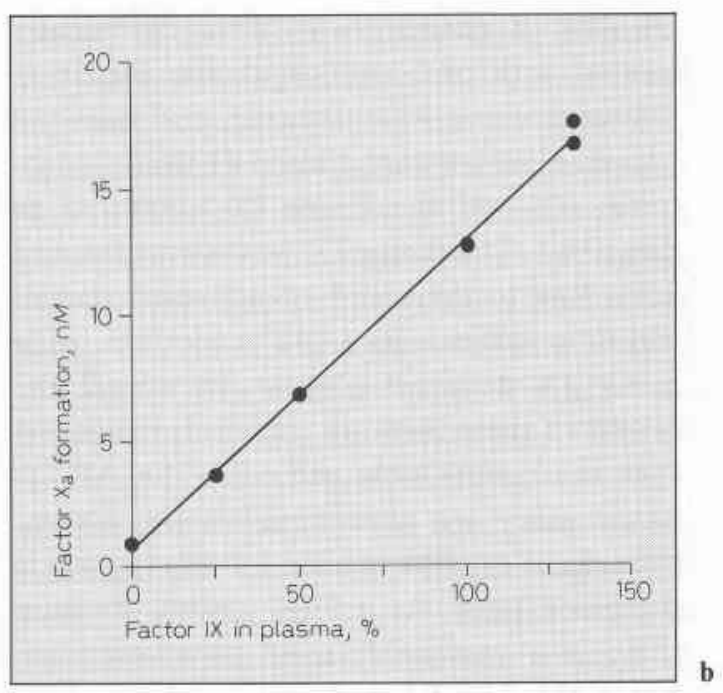

and at $t=3 \min 100 \mu 1$ reagent 2 was added. At $t=4.5$ min $500 \mu$ stop buffer (i.e., $20 \mathrm{~m} M$ ethylenediaminetetraacetic acid, $128 \mu M \mathrm{FX}_{\mathrm{a}}$ substrate, $1.6 \mu M \alpha$ NAPAP) was added, and factor $\mathrm{X}_{\mathrm{a}}$ formation was immediately measured. The final $\mathrm{CaCl}_{2}$ concentration in the reaction mixture was $13.4 \mathrm{mM}$. b $100 \mu \mathrm{l}$ reagent 2 was mixed with $25 \mu$ l diluted plasma. At $t=$ 0 min $100 \mu 1$ reagent 1 was added to start the reaction. After $3 \mathrm{~min}$ the reaction was terminated by addition of $500 \mu$ stop buffer, and the formed factor $X_{a}$ was immediately measured.

factor IX. One can observe that also in this case a linear relationship exists between the percentage factor IX and the factor $X_{a}$ formation. The blank value is higher than in figure 4 because the whole reaction mixture is used. The blank is caused by hydrolysis of the chromogenic substrate by factor $\mathrm{XI}_{\mathrm{a}}$. In figure $5 b$ the reference curve is shown for the most simplified procedure, i.e., starting the reaction with reagent 1 . Also in this case the percentage factor IX is proportional with the factor $\mathrm{X}_{\mathrm{a}}$ formation.

Using the method described in the legend to figure 5, we have measured factor IX in 
plasmas of patients who were chronically treated with oral anticoagulants. Firstly, a reference curve was prepared, and then the patient plasmas were diluted 41 times in isotonic salt and the factor IX measured as described. The factor IX was also measured according to the standard activated partial thromboplastin time (APTT) method using factor IX deficient plasma. In table 2 the results of these tests are shown. It is noticed that the results obtained with the APTTbased assay are dependent on the plasma dilution. A possible reason for this finding is discussed later. At a high plasma dilution there is a reasonable good correlation between the APTT-based assay and the chromogenic factor IX assay.

We also have investigated stability and activity of the modified reagents after lyophilization. Modified reagents 1 and 2 were prepared, divided in 2-ml amounts, and lyophilized. Their activity was tested before and after lyophilization. Before lyophilization with a plasma dilution of 1 in 41 and isotonic salt (blank), the formed amounts of factor $\mathrm{X}_{\mathrm{a}}$ were 13.76 and $0.97 \mathrm{n} M$, respectively. After lyophilization, these values were 13.74 and $1.25 \mathrm{n} M$. After 6 months, these levels were not decreased: 13.99 and $1.08 \mathrm{n} M$, respectively.

The sensitivity of the assay is determined in plasma. In ten determinations in reference plasma we found $14.15 \pm 0.419 \mathrm{n} \mathrm{M} / \mathrm{min}$, whereas for 24 blank determinations values of $0.545 \pm 0.053 \mathrm{nM} / \mathrm{min}$ were found. A variation of about $10 \%$ is found for the blank. A $1 \%$ plasma gives a rate of $0.136 \mathrm{n} M / \mathrm{min}$ in addition to the blank which is 2.5 times the standard deviation. So it is well possible to measure an amount of $1 \%$ plasma; however, to be precise, the measurement must be repeated a few times.
A field trial was performed with lyophilized reagents [26]. In this study were investigated healthy subjects, patients receiving oral anticoagulants and heparin, and various diseases, namely mild and severe hemophilia A and B, von Willebrand's disease, lupuslike anticoagulant, and others.

Our study has shown that (1) the correlation between the APTT-based clotting assay and the chromogenic assay is very well; (2) the average for normal plasma $(n=40)$ is $95.4 \pm 14.0 \%$; (3) for a patient with mild hemophilia B with the APTT-based assay $13 \%$ was found and $11 \%$ with the chromogenic assay - in case of severe hemophilia B with both assays less than $1 \%$ was found; (4) in cases of mild and severe hemophilia A with both assays similar results were found: 90 and $93 \%, 66.5$ and $62 \%, 50$ and $56.5 \%$, and 62 and $72 \%$, respectively - also in case of von Willebrand's disease the results were similar: 80 and 84 and 74 and $80 \%$, respectively, and (5) tests with factor IX concentrate showed a good correlation: with the APTT-based assay were found 20.9, 21.0, and $26.7 \mathrm{U} / \mathrm{ml}$ and with the chromogenic assay $23.1,19.6$, and $25.6 \mathrm{U} / \mathrm{ml}$.

\section{Discussion}

In this paper we have described the development of a chromogenic factor IX assay that is well suited for clinical use. Tans et al. [12] already described a spectrophotometric assay for human plasma factor IX. The main difference between the assay described by Tans et al. [12] and our assay is the use of isolated purified factor VIII. For that reason the assay described by these authors requires a much longer time to activate an appreciable amount of factor X. Another difference 
between both assays is the time needed for factor IX activation. Tans et al. [12] use a separate preactivation step of $25 \mathrm{~min}$, whereas in our case factor XI is activated in the final mixture within a few minutes. This shows that in spite of the accuracy, the method of Tans et al. [12] is not suitable for clinical use, because the procedure takes a long time, and a number of pipetting steps are necessary. The procedure described in this article is simple and requires only two pipetting steps at fixed times. The reagents necessary for the assay can be kept at room temperature during a whole working day without loosing their activity. Because of the simplicity of the method, it is well possible to automate the whole procedure. The lyophilized reagents ready for use can be obtained from Baxter.

Because we need large amounts of purified factor VIII for the factor IX assay, it was necessary to develop a new isolation procedure for bovine factor VIII. The kinetic properties of this factor VIII are comparable with those described for bovine facor VIII [25] which was isolated in a different way [27]. The removal of von Willebrand factor from the preparation can occur during two steps in the isolation procedure. During reduction of the preparation, von Willebrand factor likely will be destroyed [27] and the interaction of factor VIII with von Willebrand factor possibly is broken during binding of factor VIII to Sphérosil PL. Andersson and Brown [28] showed that this interaction is broken when the complex binds to phospholipid vesicles.

Remarkable is the finding that the factor IX assay is linear with the amount of factor IX, even at nonsaturating amounts of factor VIII. This means that under the described conditions the fraction of factor IX $_{\mathrm{a}}$ that is bound in the factor $\mathrm{X}$ activating complex fully depends on the factor VIII $_{\mathrm{a}}$ concentration and is not dependent on the factor $\mathrm{IX}_{\mathrm{a}}$ concentration. The factor $\mathrm{VIII}_{\mathrm{a}}$ concentration in the assay mixture is $1 \mathrm{U} / \mathrm{ml}$ which is about $0.7 \mathrm{n} M$. The reaction rate is about $10 \mathrm{n} \mathrm{M} / \mathrm{min}$ in case of the plasma with $100 \%$ factor IX. Assuming a turnover rate of 851 , the factor $\mathrm{X}$ activating complex concentration is $12 \mathrm{p} M$. This amount is only $1.7 \%$ of the total factor VIII $_{\mathrm{a}}$ concentration, so the change in free factor VIII $_{a}$ concentration by doubling the factor $\mathrm{IX}_{\mathrm{a}}$ concentration (at most) is only $1.7 \%$. These changes will not have any measurable effect on the fraction of factor $\mathrm{IX}_{\mathrm{a}}$ that will be bound, and thus the assay will be linear over the whole range of the assay. The plasma concentration of factor IX is about $60 \mathrm{n} M$, so the concentration of factor $\mathrm{IX}_{\mathrm{a}}$ in the assay mixture is about $100 \mathrm{p} M$ (fig. 4). This means that only $12 \%$ of the factor $\mathrm{IX}_{\mathrm{a}}$ is bound in the complete factor $\mathrm{X}$ activating complex. In case of figure 5 , this percentage is even lower (about 2\%) because of the high $\mathrm{CaCl}_{2}$ concentration.

It was shown that by increasing the $\mathrm{CaCl}_{2}$ concentration in the reaction mixture, the formation of the complete factor $\mathrm{X}$ activating complex is inhibited. At a concentration of $13.4 \mathrm{mM} \mathrm{CaCl} 2$, the activation of factor $\mathrm{X}$ by factor $\mathrm{IX}_{\mathrm{a}}$ in the absence of factor VIII $_{\mathrm{a}}$ is almost optimal [7], and also activation of factor IX by factor $\mathrm{XI}_{\mathrm{a}}$ probably is not slower than at $5 \mathrm{mM} \mathrm{CaCl} 2[29,30]$. So the inhibiting effect of a high concentration of $\mathrm{CaCl}_{2}$ is only noticed when factor $\mathrm{VIII}_{\mathrm{a}}$ is present. The mechanism of this inhibition might be decreased binding of factor $\mathrm{VIII}_{\mathrm{a}}$ to the complete factor $\mathrm{X}$ activating complex at a higher $\mathrm{CaCl}_{2}$ concentration. This phenomenon requires further investigation, but this falls outside the scope of this article. 
The finding that increasing the $\mathrm{CaCl}_{2}$ concentration decreases the activity of the complete factor $\mathrm{X}$ activating complex was used to develop an assay suitable for clinical use. Having present $13.4 \mathrm{~m} M \mathrm{CaCl}_{2}$ (final concentration) in the reaction mixture, the reaction is inhibited so much that it is not necessary to dilute plasma 200 -fold, but only 41 -fold. The plasma sample is diluted 41 times, so the final plasma dilution in the reaction mixture is 369 times. This means that clotting factors in the plasma are diluted so that they do not affect the assay, whereas inhibitors of activated clotting factors also cannot have a detectable effect on the assay. When plasma is used that is anticoagulated with $3.8 \%$ sodium citrate, the citrate concentration in plasma will be about $10 \mathrm{~m} M$ and thus in the reaction mixture $0.027 \mathrm{mM}$. This citrate will bind $\mathrm{Ca}$ ions, however, less than $0.2 \%$, so a detectable increase of the reaction rate (because less $\mathrm{Ca}$ ions are present) cannot be expected.

The lyophilization experiments have shown that the reagents 1 and 2 can be lyophilized without loss in activity. The lyophilized reagents can be stored for at least a few months without loosing their activity. These results together with the stability tests show that the assay is well suited for practical clinical use.

We have measured factor IX in different types of plasma, namely normal pooled plasma, factor IX deficient plasma, plasmas with a known percentage of factor IX (prepared by mixing normal pooled plasma with factor IX deficient plasma), and plasmas of patients who were treated chronically with oral anticoagulants. When we measured factor IX in plasmas of known factor IX concentrations, there was a good correlation between the theoretical amount of factor IX and the results found in the assay. The assay is not sensitive for other factors than factor IX; for that reason, the plasma dilution is not important. The signal is halved either when the plasma is diluted twice or when it contains $50 \%$ factor IX. Tran et al. [26] showed that the correlation between the APTT-based assay and the chromogenic assay is very well. In 1 case discrepancies were found, testing plasmas from patients receiving oral anticoagulants. The discrepancies were due to the APTT-based test system. Tran et al. [26] also showed that the amount of measured factor IX was dependent on the plasma dilution in case of the APTT test. The more the plasma was diluted, the lower percentage factor IX was detected in the plasma, whereas with the chromogenic assay at every dilution, the same percentage was found. At very high plasma dilutions the APTT gives the same result as the chromogenic assay.

We have found the same phenomenon also. In table 2 this is illustrated: the more the plasma is diluted, the lower percentage factor IX is measured. Table 2 also shows that the correlation is reasonable between the chromogenic assay and the APTT-based assay, provided that the plasma is sufficiently diluted. The reason why the result of the APTT-based assay depends on the plasma dilution still has to be determined, but this falls outside the goal of this article. It might be related to the behavior of the decarboxylated clotting factors which possibly are present in plasma of patients treated with oral anticoagulants. These oral anticoagulants (warfarin derivatives) inhibit the carboxylation (formation of $\gamma$-carboxyglutamic acid residues) of the vitamin $\mathrm{K}$ dependent clotting factors (factors IX, X, VII, and II). The decarboxylated clotting factors possibly show some activity when their concentration 
is high (thus at a low plasma dilution), but at lower concentrations they have no activity, because they have a low affinity to phospholipid membranes.

\section{References}

1 Thompson AR: Structure and molecular defects of factor IX. Blood 1986;67:565-572.

2 Lim TK, Bloomfield VA, Nelsestuen GL: Structure of the prothrombin - and blood clotting factor X-membrane complexes. Biochemistry 1977; 16:4177-4181.

3 Di Scipio RG, Kurachi K, Davie EW: Activation of human factor IX (Christmas factor). J Clin Invest 1978;61:1528-1538.

4 Østerud B, Bouma BN, Griffin JH: Human blood coagulation factor IX. Purification properties and mechanism of activation by activated factor XI. J Biol Chem 1978;253:5946-5951.

5 Davie EW, Fujikawa K: Basic mechanisms in blood coagulation. Annu Rev Biochem 1975;44: 799-828.

6 Jackson CM, Nemerson Y: Blood coagulation. Annu Rev Biochem 1980;49:765-811.

7 Van Dieijen G, Tans G, Rosing J, Hemker HC: The role of phospholipid and factor $\mathrm{VIII}_{\mathrm{a}}$ in the activation of bovine factor X. J Biol Chem 1981; 256:3433-3442.

8 Veltkamp JJ, Drion EF, Loeliger EA: Detection of the carrier state in hereditary coagulation disorders. I. Thromb Diath Haemorrh 1968;19:279308.

9 Byrne R, Amphlett GW, Castellino FJ: Metal ion specificity of the conversion of bovine factors IX, $\mathrm{IX}_{\mathrm{a}}$ and $\mathrm{IX}_{\mathrm{a}} \alpha$ to bovine factor IX $\mathrm{IX}_{\mathrm{a}} \beta$. J Biol Chem 1980;255:1430-1435.

10 Silverberg SA, Nemerson Y, Zur M: Kinetics of the activation of bovine coagulation factor $X$ by components of the extrinsic pathway: Kinetic behavior of two-chain facor VII in the presence and absence of tissue factor. J Biol Chem 1977;252: 8481-8488.

11 Enfield DL, Thompson AR: Cleavage and activation of human factor IX by serine proteases. Blood 1984;64:821-831.

12 Tans G, Janssen-Claessen T, Van Dieijen G, Hemker HC, Rosing J: Activation of factor IX by factor $\mathrm{XI}_{\mathrm{a}}$. A spectrophotometric assay for factor
IX in human plasma. Thromb Haemost 1982;48: 127-132.

13 Byrne R, Castellino FJ: The influence of metal ions in the activation of bovine factor IX by the coagulation protein of Russell's viper venom. Arch Biochem Biophys 1978;190:687-692.

14 Bligh EG, Dyer WJ: A rapid method of total lipid extraction and purification. Can J Biochem Physiol 1959;37:911-917.

15 Comfurius P, Zwaal RFA: The enzymatic synthesis of phosphatidylserine and purification by CMcellulose column chromatography. Biochim Biophys Acta 1977;488:36-42.

16 Fujikawa K, Legaz ME, Davie EW: Bovine factor $\mathrm{X}_{1}$ and $\mathrm{X}_{2}$ (Stuart factor). Isolation and characterization. Biochemistry 1972;11:4882-4891.

17 Di Scipio RG, Hermodsen MA, Yates SG, Davie EW: A comparison of human prothrombin, factor IX (Christmas factor), factor X (Stuart factor), and protein S. Biochemistry 1977;16:698-706.

18 Miletich JP, Brose GJ, Majerus PW: Purification of human coagulation factors II, IX and X using sulfated dextran beads. Methods Enzymol 1981; 80:221-229.

19 Fujikawa K, Legaz ME, Kato H, Davie EW: The mechanism of activation of bovine factor IX (Christmas factor) by bovine factor $\mathrm{XI}_{\mathrm{a}}$ (activated plasma thromboplastin antecedent). Biochemistry 1974;13:4508-4516.

20 Nossel HL: The Contact Phase of Blood Coagulation. Oxford, Blackwell, 1964.

21 Østerud B, Rapaport SI: Activation of factor IX by the reaction product of tissue factor and factor VII: Additional pathway for initiating blood coagulation. Proc Natl Acad Sci USA 1974;12:52605264.

22 Owen WG, Esmon CT, Jackson CM: The conversion of prothrombin to thrombin. I. Characterization of the reaction products formed during the activation of bovine prothrombin. J Biol Chem 1974;249:594-605.

23 Wagenvoord R, Hendrix H, Soria C, Hemker HC: Localization of the inhibitory site(s) of pentosan polysulphate in blood coagulation. Thromb Haemost 1988;60:220-225.

24 Wagenvoord R, Hendrix H, Hemker HC: Development of a simple chromogenic factor VIII assay for clinical use. Haemostasis 1989;19:196-204.

25 Van Dieijen G, Van Rijn JLML, Govers-Riemslag JWP, Hemker HC, Rosing J: Assembly of the 
intrinsic factor $\mathrm{X}$ activating complex. Interactions between factor IX $_{\mathrm{a}}$, factor VIII $_{\mathrm{a}}$ and phospholipid. Thromb Haemost 1985;53:396-400.

26 Tran THE, Zühlke U, Barrett N, Lämmle B, Wiesel ML, Cazenave JP, Wagenvoord R, Hemker HC: A novel functional chromogenic assay of factor IX. Thromb Haemost 1989;62:212.

27 Vehar GA, Davie EW: Preparation and properties of bovine factor VIII (antihemophilic factor). Biochemistry 1980;19:401-410.

28 Andersson L-O, Brown JE: Interaction of factor VIII-von Willebrand factor with phospholipid vesicles. Biochem J 1981;200:161-167.

29 Amphlett GW, Kisiel W, Castellino FJ: The interaction of $\mathrm{Ca}^{2+}$ with human factor IX. Arch Biochem Biophys 1981;208:576-585.
30 Bajaj SP: Cooperative $\mathrm{Ca}^{2+}$ binding to human factor IX. Effects of $\mathrm{Ca}^{2+}$ on the kinetic parameters of the activation of factor IX by factor $\mathbf{X I}_{\mathrm{a}}$. J Biol Chem 1982;257:4127-4132.

Received: February 8, 1990

Accepted in revised form by $\mathrm{K}$. Lechner:

May 27, 1990

Dr. R. Wagenvoord

Department of Biochemistry

University of Limburg

PO Box 616

NL-6200 MD Maastricht (The Netherlands) 